\title{
FIRM INCENTIVES TO ENGAGE IN INTERNATIONAL TRADE
}

\author{
Bohuslava Mihalčová, Luboš Socha, Pavol Bajusz
}

\section{Kl’účové slová:}

Firma. Konkurencieschopnost'. Medzinárodné podnikanie. Diverzifikácia, kapacita, bod zvratu, splatenie, vnútorná miera návratnosti.

\section{Key words:}

Company, competitiveness, international business, diversification, capacity, break-even point, payback, internal rate of return.

\begin{abstract}
Abstrakt
Spravidla identifikujeme štyri základné dôvody, pre ktoré sa firmy usilujú zapojit' do medzinárodného obchodu. V prvom rade sa jedná o rozšírenie obratu firmy na národnom trhu, ktorá je spravidla limitovaná počtom zákazníkov, ich kúpyschopnost'ou, konkurenciou a kvalitou produkcie či služieb. V druhom rade je to získavanie zdrojov, pri ktorom firma využíva komparatívne výhody jednotlivých národných ekonomík. V tret'om poradí hovoríme o diverzifikácii predaja, kedy sa podnikatel'ské subjekty snažia eliminovat' výkyvy v obrate vhodným načasovaním predaja svojich produktov na národných trhoch. V neposlednom rade ide o znižovanie konkurenčného rizika využívaním komparatívnych výhod na upevnenie ekonomickej pozície firmy, ktorá je schopná svoj zisk „prelievat““ a tak kompenzovat' straty doma ziskom v zahraničí, čím môže zostat' konkurencieschopná na domácom i zahraničnom trhu. Avšak, skôr než by sa prijali opatrenia je namieste, aby dané kritéria by boli prehodnotené z hl'adísk uvedených v záverečnej časti.
\end{abstract}

\begin{abstract}
As a rule, we identify four reasons for which companies seek to be engaged in international trade. Firstly, there are limits to the increase in the turnover within a national market due to limited number of customers, their purchasing power, competition and quality of production or services. Secondly, it is outsourcing, when a company capitalizes on the comparative advantages of national economies. Thirdly, we talk about diversification of sales when operators try to eliminate volatility in the turnover by better timing the sale of its products going beyond national markets. Finally, the competitive risk reduction by using comparative advantage to strengthen the economic position of the company that is able to go international to compensate for loss of profits at home, so that it can remain competitive both in domestic and foreign markets. Before real courses of actions are taken, the incentives are to be subjected to validation in terms of the validation criteriae as outlined in the final part of the article
\end{abstract}

\section{Introduction}

The present times are characterized by the development of international trade and a a relatively rapid growth of cooperation among companies resulting in various alliances. European firms, confronted with the need to adapt to the common market, formation of the European monetary union and the increasing globalization of market, are more focused on acquisition strategies. They are looking for ways of competitiveness, formulating stategies and key factors of success and obtain benefits not only from the domestic but also international areas of operation. This contribution is dealing with the search for profit by way of motivating and developing strategies at an international scale. Based on current 
events (economic crisis), the article defines international business and international trade in the context of world economics.

\section{Economic crisis and international business}

Among the reasons that motivate companies to enter and become part of the international busdinesspreneruship environment are the ones like search of new markets, cutting costs through international entreprehneurship, or optaining access natural resources in foreing countries. Such is the environment within which international business is made. It involves all the transactions performed among individuals, companies, either private or public, subjects, states or groups of other kinds, bridging over national boundaries. However, the current international entrepreneurship is strongly demotivated by the economic crisis.

Words on the looming economic crisis have started in the middle of the year 2007 referring to the mortgage crisis in the United States of America ${ }^{1}$.

It was the US real estate market crisis that gave extra momentum to the depression. The reason consisted in the fact that banks were offering low interest rates mortgage loans for inhabitants with lower level of income. The light-headed approach to the financial misstatements of rating agencies presenting clients at risk (see Fig. 1). In the course of the following years the interest rates have began to grow to high levels, and the locals were longer able to pay for the mortgages ${ }^{2}$.

„Our" famous economist Mr. Peter Staněk distinguishes two groups of causes that contributed to the economic crisis. The first is about the low -level of regulation applied to financial markets. Governments have adopted a loose approach towards limitations and regulations, firstly applyied mostly in the commodity market leading to the rise in the business and in 2008 to the rise of prices like those of the oil, oil products and basic food. Simultaneously, the same period saw the provision of mortgage loans for groups of inhabitants at a high risk in terms of their capability of paying down their debts. The second group of causes is termed as the one of insufficient measures of stimulation ${ }^{3}$.

Provision of risk loans has led to immense growth in indebtedness on the part of the inhabitants surpassing their real potentials. Gradually it has caused migration of capital from European banks as US mortgage institutions lacked financial resources. All that resulted in rising the price levels at real estates, thereby, limiting extension of further credits. It helped create the so-called virtual bubble of mortgages that upon its burst negatively affected not only the US economy but that of the Europe, as well ${ }^{4}$.

One of the symptoms of economic crisis is the unemploment. By the Trend Analyses expert, Michal Lehuta, it was the crisis that caused mass layoffs affecting the unemployment rate to the end of $2008^{5}$. There followed a general rise in the prices of goods, services and raw materials, energy causing problems even at international business (further only IB), a subsystem of international entrepreneurship. Companies must be highly sensitive in their formulating the optimal strategy of business and rely only on those key factors of success that would help become successful even under deteriorating conditions of these days.

\footnotetext{
${ }^{1} \mathrm{http}: / /$ www.unitedone.sk/index.php?option=com_content\&task=view\&id=42\&Itemid=9, (Cit. 04.01.2010).

${ }^{2}$ http://www.epi.sk/456/Vznik-financnej-krizy_13316.aspx,, (Cit. 04.01.2010).

3 http://www.akademickyrepozitar.sk/peter-stanek/odhalenie-pricin-hospodarskej-krizy, (Cit. 31.12.2009).

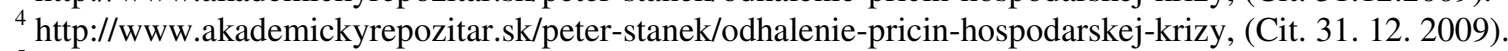

${ }^{5} \mathrm{http}$ ://ekonomika.etrend.sk/ekonomika-slovensko/na-nezamestnanosti-uz-citit-krizu.html, (Cit. 04.01.2010).
} 


\begin{tabular}{|c|c|c|c|}
\hline & Interest rates & Credit market & $\begin{array}{l}\text { Real estate } \\
\text { Demand and Supply }\end{array}$ \\
\hline 2003 & \multirow{3}{*}{$\begin{array}{l}\text { Low interest rates } \\
\text { introduced by the FED } \\
\text { to support economic } \\
\text { growth. }\end{array}$} & \multirow{3}{*}{$\begin{array}{l}\text { Credit expansion and } \\
\text { securitization } \\
\text { mortgages na follow-up } \\
\text { transfer of risk on the } \\
\text { thrid parties. High rating } \\
\text { of these securities. } \\
\end{array}$} & \multirow{3}{*}{$\begin{array}{lrr}\text { High demand on } & \text { real } \\
\text { estate supported } & \text { by } \\
\text { rising } & \text { prices } & \text { and } \\
\text { availability } & \text { of } \\
\text { credits.Subsequent } & \text { rise } \\
\text { in the supply of } & \text { real } \\
\text { estates. } & & \\
\end{array}$} \\
\hline 2004 & & & \\
\hline 2005 & & & \\
\hline 2006 & \multirow[t]{2}{*}{$\begin{array}{l}\text { Incresing interest } \\
\text { rates in the light of the } \\
\text { threatening inflation. }\end{array}$} & \multirow{2}{*}{$\begin{array}{l}\text { Credit crisis - resetting } \\
\text { of low credit rates, } \\
\text { inability of paying back } \\
\text { credits and the } \\
\text { consequent deliquency. }\end{array}$} & \multirow{2}{*}{$\begin{array}{l}\text { Decreasing demand on } \\
\text { real esate caused by } \\
\text { worsening avalilability } \\
\text { of Money and credits. } \\
\text { Deliquencies } \\
\text { oversupply. }\end{array}$} \\
\hline 2007 & & & \\
\hline & \multirow[b]{2}{*}{$\begin{array}{l}\begin{array}{l}\text { Emergency reduction } \\
\text { of interest rates (FED }\end{array} \\
1 \% \text {, ECB 2,5\% from } \\
\text { interest rate maxima } \\
\text { reached in } 2007 \text { August } \\
\text { FED 5,25\%, and } \\
\begin{array}{ll}\text { October } 08 \text { ECB } \\
3,25 \%) .\end{array}\end{array}$} & \multirow[b]{2}{*}{$\begin{array}{l}\text { Distrust in the } \\
\text { interbank market (high } \\
\text { referential rates, } 3 \mathrm{~m} \\
\text { LIBOR at USD reaching } \\
\text { in October } 08 \text { almost } \\
5 \% \text { - prime rate at } 1,5 \% \text { ). }\end{array}$} & \multirow{2}{*}{$\begin{array}{l}\text { Weakening } \\
\text { consumption, } \\
\text { a continuing decrease in } \\
\text { demanod on real } \\
\text { estates. }\end{array}$} \\
\hline 2008 & & & \\
\hline
\end{tabular}

Fig. 1 Time line of the financial crisis

Source: www.cikomodity.com, (Cit. 10.01.2010).

\section{Links between international business and the world economic environment}

International entrepreneurship is a wider notion than that of the IB, as business is only one of the parts of entrepreneurship. IB is the result of the international division of labour. Currently, every country in the world is practically dependent on the international divison of labour which is characterized by specialization and cooperatinion in manufacturing. These economic relations result in economic interdependency the essence of which is in mutual dependency of countries on economic cooperation. Another consequence of international division of labour is termed as the economic integration, IB has developed to match the world-scale player already in the 19th scentury. Conditions to it were given through the invention of power plants, engines and electricity, tlegraph and the telephone as well as by the industrial revolution and the trade between "metropoles“ and colonies. IB ${ }^{6}$ involves exchange of goods and services between groups of countries within an international economic alliances. More and more is shared in the IB through services. The international trade of services means that economic entities residing in different countries are exchanging equal economic values by way of property transfer, all that independently of the location where the transaction takes place. At present two contradicting tendencies are practiced:

\footnotetext{
${ }^{6}$ http://referaty-seminarky.sk/svetove-hospodarstvo-medzinarodny-obchod/, (Cit. 05.01.2010).
} 
- liberalism, typical of gradual elimination of obstacles hindering free motion of goods, services and the capital. Tereby, states are facilitating further development of the IB on the basis of bilateral or multilateral agreements and multinational institutions.

- protectionism, involving measures on the part of countries to protect internal market or domestic economy against competition from abroad.

IB can exist under the following conditions:

$>$ Expansion in the introduction of more and more progressive technologies,

$>$ Liberalization of government policies relating movement of trade and resources over national boundaries,

$>$ Formation and development of institutions supporting IB,

$>$ Competition an competitive struggle among companies.

The enviroment for international entrepreenurship, with the IB included, is made up of the global economic environment. One of the important factors of the growth are the structuraladaptation processes taking place in economis on a continuous and purposeful bases.

\section{Motivation of companies to join international business and their strategies of entrepreneurship}

The following part of the contribution is devoted to considerations why companies are ambitious to enter the IB. Exporting goods often means higher turnouver and profits bringing in larger resources for further investments, development, repeated production and sales on international markets, i.e. the circular flow of entrepreneurship activities. Import is usually both a must (raw materials, technologies) and an advantage (unfinished products, copoperation deliveries). The times of stagnation or even decline in the IB are barriers to the growth of world-scale manufacturing and services ${ }^{7}$,international specialization and cooperation in manufacturing, insvetments, hindering flow of capital and international entrepreneurship of companies. The negative economic development wordlwide results in slowing down or even stopping the development ofthe IB. Reducing tariffs, softening notariff barriers are offering oportunities for making business on international markets. Consequently, the new products and services can be instrumental in opening propsective, today non-existing markets, and are of higly motivational and developmental effect on both the IB and manufacturers. When formulating strategies at international level, companies are motivated to enter the IB mostly for the following reasons: As first, it increases company turnover at the national market which is, as a rule, limited by the number of customers, their purchase power, competition and the quality of products or services. As second comes the acquisition of resources, when firms are making use of the comparative advantages of national economies. The third-in-order factor is that of the diversification of sales, when the business entities are trying to eliminate the turnover fluctuations by properly timing the sales of their products at national markets. Last but not least, it is the reduction of the competition risk by making use of the comparative advantage to consolidate the economic position of the company, which is capable of „transferring“ its profit thereby compensating for losses from the domestic market by the profit from the international environment, thus remaining competitive both at domestic and international markets.

\footnotetext{
${ }^{7}$ http://www.google.sk/search?q=\%22svetov\%C3\%A9+hospod\%C3\%A1rstvo\%22\&hl=sk\&lr=lang_sk\&client=f irefox-a\&hs=59h\&rls=org.mozilla:sk:official\&channel=s\&tbs=lr:lang_1sk\&start=10\&sa=N, (Cit. 10.01.2010).
} 
Development of a strategy for international entrepreneurship requires, appart from taking into account the national diversities in terms of customer needs, habits, local market potentials for growth, its driving forces, distribution channels, intensity of the competition, paying due attention to the specific features of international business ${ }^{8}$, such as cost differences between countries, fluctuation of exchange rates, economic policies of the host country and forms of international competion. J. Ellis an D. Williams ${ }^{9}$ identified four independent phases of the development in international buisness, namely the limited environment of the domestic market, entry on the international market and the development of international presenceon the regional, international and world-wide market. A company, acting within a limited, national market, has no regular business with foreign countries. It is involved performing only in occasional export, when the momentary conditions are extremely beneficial. Local market orientation is dominant in small-, and medium-size businesses.

Entering the international market means presence of the company at one market, or at a small group of international markets. Sustainability and development of this phase of internationalization is often the crucial point of the company growth, as both the size and complexitiy of the organization is increasing along with the risk of entrepreneurship. In most cases, manufacturing companies are entering international markets by exporting products made by the domestic production base. Export is realized by making use of a third-party agent (distribution agent) or by way of setting up an own sister company for direct sales and marketing at the international market. The market area is becoming internationalized, while manufacturing remains in the domestic environment.

\section{Validation of the incentives as a means of approaching further}

Once we have been able to define the decisive incentives for international trade, there arises the question, how to use them. The problem remains with looking for the driving forces acting behind the scenes that would be helpful in considering the incentives mentioned. From technical point of view, they can be viewed as factors. Regardles which of them we chose, it is important to judge them by applying the common sense that mostly requires assessment in view of one's production capacity, internal economics and external prospects.

Capacity is viewed as the foremost aspect to be considered when increasing turnover is in question. On the one hand ther first thing to consider is the economics of scales, i.e. the larger the production the lower the unit cost for a single item produced. It is applicable mostly for cases, when there are unused capacities within a company short of local market demands. This results in reserves of manufacturing, so there is no need to extend the existing capacity of production. Logically, it is about becoming aware of the cost - related aspect of making best use of the existing production capacity. As a further solution, from this point of view, consists in finding free capacity in our target country. All that, however, is possible to a certain level of production, as any further increase in the production capacity may necessitate extension of the technological backround, with a certain economic impact on the company as a whole.

Assessing the internal economic situation of the company is only a logical step forward from the previous position. Increasing capacity over the existing potential is coupled with

\footnotetext{
${ }^{8}$ SLÁVIK, Š.: Strategický manažment. - Bratislava : Sprint vfra, 2005, 404 s., ISBN 80-89085-49-0

${ }^{9}$ ELLIS, J. - WILLIAMS, D. : International Business Strategy. PITMAN Publishing, London, 1995, s. 54
} 
increased outlays on all the factors participating in the production process, i.e. both fix and variable ones. The break-even point analysis is able to show at what capacity the manufacturing plant is able to cover its costs and become profitable. One has also take into consideration the potentials for selling the resulting higher stock of products, either at home or abroad. A similar tool is at hand in the form of evaluating the gradual increase in the production versus the revenues obtained from adding extra product, i.e by the law of the diminishing returns. This approach adds more emphasis on assessing one's own capacity in view of the company's internal economic constraints. It is about solving the age-old dilemma: either to produce or contract out. ${ }^{10}$

A specific area of asessing the viability of incentives is based on external economic relations. It is about reconsidering the economic potentials of our company as an investment opportunity. An important aspect is in our ability to change viewing our company as if from the outside, i.e. from the point of our foreign partners of future cooperation. Our firm is to be viewed foremostly by market value of the company, i.e market value versus the book value of its stocks. As a matter of course, the higher the ratio, the higher the interest for cooperation or prospects for future investment. Another important criterion is viewing our company as an investment opportunity. Then the aspect of the rate of return either in terms of partial or overal investments. Besides the classical way of calculating the pay-back period, the investors are interested in the present value of the revenues from the investment, as the decisive factor in assessing the company's ability to cover both the initial investments in the light of current inflow of revenues, either as a partial investment or the company as a whole.

\section{Conclusion}

International business provides acces to international markets for lots of local companies. The openness of the local market for international products and services addes to the competition to the benefit of local consumers. Experiences from the past show that it is difficult to become rich unless one is open to international business. The currently ongoing world economic crisis is raising anxiety from increased protectionistic measures ${ }^{11}$, which could further deepen the world economic crisis. In the time of the Great depression of the 30 s of the former century, it was protectionism that contributed most to the economic decline. At the present time, when the majority of world economies has fallen into recession, the creators of economic policies are under the pressure of local entrepreneurial circles to introduce protectionistic measures. Theory and practice in the IB maintains that protectionism has proven harmful to such countries, especially in the long run. It would would have been much more useful to concentrate on building the competiveness of their economies through programmes of business environment development.

The aspects that help validate the incentives for going international offer a certain mirror that should be looked into before taking the future courses of actions. It is foremostly about considering at least three decisive factors, i.e. one's own capacity, revenues from extra costs incurred and, last but not least, the participation in international business as part of investment programmes, where market value of stocks and rate or return are among the fundamental criteria of eligibility in view of prospective partners from abroad. To sum up, the more earnest approach is taken in evaluating incentives, the more reliable picture of

\footnotetext{
${ }^{10}$ FRANK H.R.: Microeconomics and Behaviour , McGraw-Hill, Inc. US 1991, ISBN 0-07-021870-6.

11 http://nazory.pravda.sk/medzinarodny-obchod-v-ohrozeni-d3f-/sk-nana.asp?c=A090414_150734_sknana_p29, (Cit. 10.01.2010).
} 
our potentials for going international can be obtained. In order to survive in the highly volatile and risky business environment of the world, managers are expected to start considering aspects falling within their compentence, i.e capacity, internal economy and company investment value and those ascertained only by way of participation in the market, often falling beyond their reach.

\section{References:}

[1] ELLIS, J. - WILLIAMS, D. : International Business Strategy. PITMAN Publishing, London, 1995, s. 54

[2] FRANK H.R.: Microeconomics and Behaviour, McGraw-Hill, Inc. US 1991, ISBN 007-021870-6.

[3] LESNIAKOVÁ, A. - CEHLÁR, M.: Podnikatel'ský plán a inovácie. Košice: Edičné stredisko/AMS, Fakulta BERG, 2004. ISBN 80-8073-083-0

[4] SLÁVIK, Š.: Strategický manažment. - Bratislava : Sprint vfra, 2005, 404 s., ISBN 8089085-49-0

[5] http://www.unitedone.sk/index.php?option=com_content\&task=view\&id=42\&Itemid=9 , (Cit.04.01.2010).

[6] http://www.epi.sk/456/Vznik-financnej-krizy_13316.aspx, (Cit. 04.01.2010).

[7] http://www.akademickyrepozitar.sk/peter-stanek/odhalenie-pricin-hospodarskej-krizy, (Cit.31.12.2009).

[8] http://ekonomika.etrend.sk/ekonomika-slovensko/na-nezamestnanosti-uz-cititkrizu.html, (Cit.04.01.2010).

[9] http://referaty-seminarky.sk/svetove-hospodarstvo-medzinarodny-obchod/, (Cit. 05.01.2010).

[10] http://www.google.sk/search?q=\%22svetov\%C3\%A9+hospod\%C3\%A1rstvo\%22\&hl=s $\mathrm{k} \& l \mathrm{r}=$ lang_sk\&client=firefox-

a\&hs=59h\&rls=org.mozilla:sk:official\&channel=s\&tbs=lr:lang_1sk\&start=10\&sa=N, (Cit. 10.01.2010).

[11] http://nazory.pravda.sk/medzinarodny-obchod-v-ohrozeni-d3f-/sknana.asp?c=A090414_150734_sk-nana_p29, (Cit. 10.01.2010).

[12] www.cikomodity.com, (Cit. 10.01.2010).

\section{Classification JEL: F-13}

\section{Bohuslava Mihalčová, doc. Ing. PhD., mimoriadna profesorka}

Ekonomická univerzita v Bratislave

Podnikovohospodárska fakulta v Košiciach, Katedra manažmentu

Tajovského 13

04130 Košice, Slovensko

mihalcova.b@seznam.cz

\section{Ing. Luboš Socha, PhD., Ing. Pavol Bajusz}

Technická univerzita v Košiciach

Letecká fakulta

Rampová 7

04012 Košice, Slovensko

lubos.socha@tuke.sk,pavol.bajusz@tuke.sk 